\title{
Prospective Zinc Solubilizing Microorganisms for Enhanced Growth and Nutrition in Maize (Zea mays L.)
}

\author{
Sukanya Ghosh*, Navneet Pareek, K. P. Rawerkar, R. Chandra, \\ S. P. Pachauri and Shikhar Kaushik
}
Department of Soil Science, Govind Ballabh Pant University of Agriculture and Technology, Pantnagar, U.S. Nagar, Uttarakhand-263145, India

*Corresponding author

\begin{abstract}
A B S T R A C T
\section{Keywords}

Zinc solubilizing bacteria, Aspergillus sp., Bacillus sp., zinc oxide, solubilization

Article Info

Accepted:

22 July 2019

Available Online:

10 August 2019

Zinc $(\mathrm{Zn})$ is one of the most essential micronutrients required for normal plant growth and development. Even though considerable quantity of inorganic $\mathrm{Zn}$ is applied in soil but significant quantity of it gets converted into unavailable forms. $\mathrm{Zn}$ solubilising microorganisms are the potential substitute for $\mathrm{Zn}$ supplement to plant from soil. Among the four isolates that were screened for $\mathrm{Zn}$ solubilization, fungal ones performed better than bacterial ones and Aspergillus sp. in particular, outperformed every other isolate in the test. It produced a clear halo zone of $22.7 \mathrm{~mm}$ on solid medium amended with $\mathrm{ZnO}$. It also produced the biggest halo zone on $\mathrm{ZnCO} 3$ amended media which was followed by Penicillium sp. and Bacillus megaterium. Aspergillus sp. also gave significant release of $\mathrm{Zn}$ in broth assay amended with $\mathrm{ZnO}$ and $\mathrm{ZnCO}_{3}(88$ and $62 \mathrm{ppm})$, respectively. The $\mathrm{pH}$ of the broth was acidic in all the cases ranging from 4.6 to $6.4 \mathrm{in} \mathrm{ZnO}$ and from 5.1 to 6.7 in $\mathrm{ZnCO}_{3}$ amended media. A pot culture experiment with maize for 60 days was conducted which revealed that seed inoculation with Aspergillus sp. superiorly enhanced total dry weight of plant (63.21 g/plant) and N (2.42\%), P (0.432\%) and $\mathrm{Zn}(25.79 \mathrm{ppm})$ contents.
\end{abstract}

\section{Introduction}

Among micronutrients zinc ( $\mathrm{Zn})$ is one of the most crucial nutrient that is required in moderately less concentrations (5 to 100 $\mathrm{mg} / \mathrm{kg}$ ) in plants tissues for their optimum growth and development. Deficiency of this nutrient in plants has been reported to give rise to stunted growth, reduced integrity of cell membrane, less production of carbohydrates, repair of cell along with decreased synthesis of vital cell organelles such as cytochromes, nucleotides. It also leads to increased susceptibility to abiotic stresses. Imbalanced use of zinc containing fertilizers create a problem for human beings too as it is known to impair the body absorption of other nutrients like copper and iron. It may also cause anomaly in reproductive health in males (Sharma et al., 1990). Zn solubility is highly dependent on soil $\mathrm{pH}$ and soil moisture and this may be one of the reasons for its low availability in dry arid regions of India resulting in $\mathrm{Zn}$ deficient soils. Maize is grown in diverse climatic conditions in India from arid to humid regions. It is cultivated in about 
8.26 Mha area with an yield of $19 \mathrm{Mt}$ (Ministry of Agriculture, Government of India). Plenty of literature has cited that grain $\mathrm{Zn}$ content is inherently low particularly if crop is grown of $\mathrm{Zn}$ depleted soils. The main reason of this occurrence is due to low dissolution of $\mathrm{Zn}$ in soil. Conventional application of this nutrient to soil somewhat meets the plant demand as more than 90 percent of $\mathrm{Zn}$ gets converted to insoluble form depending on physicochemical reactions and type of soil on which it is applied within days of its application. Microorganisms are the prospective replacements that could cater to plant $\mathrm{Zn}$ requirement by solubilizing the complex and insoluble forms of $\mathrm{Zn}$ in soil. Several species within bacteria and fungi have been reported to solubilize $\mathrm{Zn}$ most of which belong to the genera of Bacillus, Pseudomonas and Aspergillus species. These organisms solubilize the metal via several biochemical pathways such as chelated ligands, production of keto-glutonic acids thereby reducing surrounding $\mathrm{pH}$, extrusion of protons which are present on their membranes (Cakmak, 2008; Saravannan et al., 2004). They are also known for their plant growth promoting traits such as production of regulatory hormones, vitamins, siderophores and antibiotics. In this study the ability to solubilize $\mathrm{Zn}$ in vitro of four microbes and their effect on growth enhancement of maize has been reported (Crane et al., 1985; Hughes and Poole, 1981; Wakatsuki, 1995).

\section{Materials and Methods}

\section{Microbial Cultures}

The bacterial strains that were used in the experiment were procured from Agricultural Research Station, Parbhani, India which belong to Bacillus species namely, Bacillus subtilis and Bacillus megaterium. The fungal strains (Aspergillus sp. And Penicillium sp. identified on the basis of morphology) were isolated from rhizopheric $\mathrm{Zn}$ deficient soils from college farm by serial dilution technique. Further purification was achieved by streak plate method. All four cultures were maintained on nutrient agar and potato dextrose agar media at $4^{0} \mathrm{C}$.

\section{In Vitro Zinc Solubilization Assay}

All four isolates were inoculated into Pikovaskaya media (g/L) specified by Saravanan et al., containing dextrose: 10.0; $\left(\mathrm{NH}_{4}\right)_{2} \mathrm{SO}_{4}: \quad 1.0 ; \quad \mathrm{KCl}: \quad 0.2 ; \quad \mathrm{K}_{2} \mathrm{HPO}_{4}: \quad 0.1$; $\mathrm{MgSO}_{4}$ : 0.2; pH: 7.0 and insoluble $\mathrm{Zn}$ salts ( $\mathrm{ZnO}$ and $\mathrm{ZnCO}_{3}: 0.1 \%$; Agar: $15.0 \mathrm{~g}$ ) and autoclaved at $121^{0} \mathrm{C}$ for $20 \mathrm{~min}$. Actively growing cultures of each strain were spotinoculated with sterilized toothpick onto the agar plates and were incubated at $28^{\circ} \mathrm{C}$ for 3-5 days. The halo zone around colony was observed and recorded. Quantitative assay of zinc solubilization was studied in $150 \mathrm{~mL}$ conical flasks containing $50 \mathrm{~mL}$ of liquid Pikovaskaya medium. The broth was inoculated with $0.5 \mathrm{~mL}$ of overnight grown bacterial and fungal inoculums and incubated for 3-4 days in an incubator at $28 \pm 2{ }^{\circ} \mathrm{C}$. After incubation, the culture broth was centrifuged and $\mathrm{Zn}$ concentration in supernatant was estimated using atomic absorption spectrophotometer.

\section{Seed Inoculation}

Seeds of maize of cultivable variety were firstly surface sterilized with $1 \%$ sodium hypochlorite for $5 \mathrm{~min}$ and then washed thoroughly three times with sterile distilled water. The seeds were dipped in liquid media containing inoculum of each isolate and air dried.

\section{Pot Trial}

A pot culture experiment was conducted in plastic pots $(20 \mathrm{~cm} \mathrm{dia})$ of $4 \mathrm{~kg}$ capacity and 
filled with $2.5 \mathrm{~kg}$ of sterile soil (pre sterilized for two consecutive days in autoclave) with three replications for each treatment. Maize seeds were treated with inoculants and were sown in pots at $5 \mathrm{~cm}$ depth under glasshouse condition. Pots were watered daily with sterile distilled water for 60 days.

The experimental setup consisted of 15 treatments namely, five treatments of isolates (two each of bacteria and fungi and an uninoculated control) and two nutrient sources of $\mathrm{Zn}$ as $\mathrm{ZnO} @ 12.5 \mathrm{~kg} / \mathrm{ha}$ and $25 \mathrm{~kg} / \mathrm{ha}$ along with recommended dose of fertilizer. Five plants per pot were sown.

\section{Plant Growth Measurement}

The crop was harvested after 60 days of sowing (DAS). Maize plants were carefully uprooted from each pot and plant growth parameters like, plant height, stem girth, and dry matter weight were recorded.

\section{Nutrient Analyses}

The plant samples were dried under shade and were ground finely in a mortar and pestle and $0.1 \mathrm{~g}$ of powdered sample was taken in $150 \mathrm{~mL}$ conical flask containing $10 \mathrm{~mL}$ nitric acid and perchloric acid in the ratio 9:4.The flasks were placed on a hot plate and digested at $300^{\circ} \mathrm{C}$ until the entire material turned into colourless liquid avoiding charring. The colourless extract was collected in $100 \mathrm{~mL}$ volumetric flask and the volume was made to $100 \mathrm{~mL}$ with distilled water. These samples were then used for estimation of zinc by AAS, potassium by flame photometer, nitrogen and phosphorus by Kjeldahl and Olsen methods respectively (Tandon, 2001).

\section{Statistical Analysis}

The data generated was subjected for analysis of variance as applicable two factorial CRD to test differences among the treatment means as described by Gomez and Gomez, 1984.

\section{Results and Discussion}

\section{Zinc Solubilization Activity}

All four isolates used efficiently solubilized the insoluble $\mathrm{Zn}$ salt amended media, which were $\mathrm{ZnCO}_{3}$ and $\mathrm{ZnO}$, under in vitro conditions. The halo zone diameter was greater in $\mathrm{ZnO}$ amended medium than $\mathrm{ZnCO}_{3}$. Size of the clear zone diameter ranged from 8.3 to $22.7 \mathrm{~mm}$ in $\mathrm{ZnO}$ and from 7.4 to $17.6 \mathrm{~mm}$ in $\mathrm{ZnCO}_{3}$ amended medium. Among the isolates, fungi showed more solubilization over bacterial ones and overall Aspergillus sp. had the highest zone of solubilization followed by Penicillium sp. And Bacillus megaterium in both $\mathrm{ZnO}$ and $\mathrm{ZnCO}_{3}$ amended media. In $\mathrm{ZnO}$ amended media Aspergillus sp. showed a diameter of $22.7 \mathrm{~mm}$ followed by Penicillium sp. $(18.5 \mathrm{~mm})$ whereas in $\mathrm{ZnCO}_{3}$ amended media Aspergillus sp. displayed a diameter of $17.6 \mathrm{~mm}$ followed by Penicillium sp. (14.9 $\mathrm{mm}), B$. megaterium $(10.7 \mathrm{~mm})$ and lastly $B$. subtilis $(7.4 \mathrm{~mm})$.Quantitative assay of $\mathrm{Zn}$ solubilisation exhibited that Aspergillus sp., Penicillium sp. and B. megaterium were able to dissolve 88,62 , and $33 \mathrm{ppm}$, respectively from $\mathrm{ZnO}$ (Figure 1) in broth on seventh day of observation and were in accord to the observations made on solid medium. Hence, Aspergillus sp. And B. megaterium were found to be the major solubilizers on both plate and broth study but the fungal isolates were the dominant solubilizers in both cases. Among the treatments, significant reduction of $\mathrm{pH}$ was observed in the broth medias incorporated with $\mathrm{ZnO}(\mathrm{pH}$ 4.6-6.4) (Figure 1) and $\mathrm{ZnCO}_{3}(\mathrm{pH} \mathrm{5.1-6.7)} \mathrm{but} \mathrm{no} \mathrm{significant}$ correlation was observed between the $\mathrm{pH}$ and solubilization of $\mathrm{Zn}$. Zn solubilization can be achieved via a variety of mechanisms by microorganisms, which include secretion or excretion of metabolites such as organic acids, 
proton extrusion, or production of chelating agents $[12,13]$. Also production of mineral acids such as sulphuric acid and carbonic acid may also facilitate the solubilisation of the nutrient in soil $[8,14]$. From the given data it was revealed that zinc solubilization potential differed with each isolate. Reduction in $\mathrm{pH}$ of the supernatant and its acidification was observed for all four isolates.solubilizing potential was also correlated with the amount of zinc that had been accumulated by plant. For this study $\mathrm{Zn}$ solubilization and fall in media $\mathrm{pH}$ could be due to production of organic acids, like 2-keto-gluconic acids. Zinc phosphate solubilization by Pseudomonas fluorescens was studied by Di Simine et al., where they stated that gluconic acids produced in the culture medium mediated the solubilization of insoluble zinc salts. In the present investigation too, the $\mathrm{pH}$ in acidic range shown by all isolates supports the fact that $\mathrm{Zn}$ solubilization could be due to production of organic acids and higher the production of the same more is the available zinc content in the culture broth. Desai et al., (2012) observed that higher availability of $\mathrm{Zn}$ is directly proportional to acidic $\mathrm{pH}$ of the culture broth. Similar results were also registered by Fasim et al., (2002), Saravanan et al., (2003) and Countinho et al., (2012).

\section{Plant Growth Promoting Activity of Bacterial Strains}

Seed inoculation of maize with zinc solubilizing isolates significantly enhanced the plant growth at 30 DAS and after 60 DAS (Table 1). Varying nutrient levels also had a significant influence on plant height of maize at different crop growth periods. At 30 DAS maximum and significant increase was observed due to application of $\mathrm{ZnO} @ 25$ $\mathrm{kg} / \mathrm{ha}(48.53 \mathrm{~cm})$ followed by $\mathrm{ZnO} @ 12.5$ $\mathrm{kg} / \mathrm{ha}(46.91 \mathrm{~cm}) . \mathrm{ZnO} @ 25 \mathrm{~kg} / \mathrm{ha}$ application enhanced plant height over RDF by $8.3 \%$ at 30 DAS while ZnO @ $12.5 \mathrm{~kg} / \mathrm{ha}$ increased it over by $4.7 \%$. At 60 DAS application of $\mathrm{ZnO}$ @25 kg/ha (132.33 cm) and ZnO @ 12.5 $\mathrm{kg} / \mathrm{ha}(127.33 \mathrm{~cm})$ registered significant gain in height over RDF $(118.10 \mathrm{~cm})$ by $12 \%$ and $7.7 \%$, respectively. Inoculation also affected the height of maize plants with maximum significant gain being with Aspergillus (54.44 $\mathrm{cm})$ and Penicillium $(51.95 \mathrm{~cm})$ over no inoculation $(38.57 \mathrm{~cm})$ by $41.4 \%$ and $34.7 \%$ respectively at 30 DAS. At 60 DAS inoculation with Aspergillus significantly increased the plant height by $18.4 \%$ followed by Penicillium and B.megaterium by $14.4 \%$ and $13.6 \%$ respectively, over no inoculation. The interaction effect between inoculants and nutrients was significant. The maximum plant height $(55.57 \mathrm{~cm})$ was measured due to inoculation with Aspergillus sp.+ $\mathrm{ZnO} @ 25$ $\mathrm{kg} / \mathrm{ha}$ which was greater by $44.6 \%$ as compared to uninoculated control at 30 DAS. Between bacterial isolates maximum gain was observed by interaction of $B$. megaterium with $\mathrm{ZnO} @ 25 \mathrm{~kg} / \mathrm{ha}(48.30 \mathrm{~cm})$. Interaction effects of Aspergillus sp. with both nutrient levels except showed significant gain in height over RDF. Also all inoculants performed significantly well with both levels of $\mathrm{ZnO}$. The best interaction effect at 60 DAS was observed with Aspergillus sp. + ZnO @ 25 $\mathrm{kg} / \mathrm{ha}(143.33 \mathrm{~cm})$ followed by both Aspergillus sp. and Penicillium sp. with $\mathrm{ZnO}$ @ $25 \mathrm{~kg} / \mathrm{ha}$ which were at par with each other $(139.33 \mathrm{~cm})$. The varying nutrient levels significantly influenced the stem girth \{Table $2)$. At 30 DAS the maximum and significant increase of $18.1 \%$ over RDF $(1.43 \mathrm{~cm})$ was recorded with the application of $\mathrm{ZnO} @ 25$ $\mathrm{kg} / \mathrm{ha}$ and by $10.4 \%$ by $\mathrm{ZnO} @ 12.5 \mathrm{~kg} / \mathrm{ha}$. Effect was also significant with maximum increase of $4.3 \%(2.39 \mathrm{~cm})$ by application of $\mathrm{ZnO} @ 25 \mathrm{~kg} / \mathrm{ha}$ over RDF $(2.29 \mathrm{~cm})$ at 60 DAS. Zn solubilizers also significantly affected stem girth at 30 and 60 DAS. At 30 DAS the highest stem girth was resulted due to inoculation with Aspergillus sp. $(1.78 \mathrm{~cm})$ increasing it by $35.9 \%$ over no inoculation 
$(1.31 \mathrm{~cm})$. At 60 DAS, inoculation with Aspergillus sp. enhanced the girth by $8.5 \%$ followed by Penicillium sp. (7.6\%) and $B$. megaterium by $4.9 \%$ over no inoculation. Interaction effects, at 30 DAS were recorded significant due to all combinations of inoculants and nutrients with highest being with Aspergillus sp.+ $\mathrm{ZnO} @ 25 \mathrm{~kg} / \mathrm{ha}$ and Aspergillus sp. + ZnO@ $12.5 \mathrm{~kg} / \mathrm{ha}$. The increase due to both treatments was to the tune of $55.6 \%$ and $48.7 \%$ respectively, over RDF. An increase of $43.9 \%$ over RDF was recorded also due to Penicillium sp. + ZnO @ $25 \mathrm{~kg} / \mathrm{ha}$ and of $48.7 \%$ by B. megaterium+ $\mathrm{ZnO} @$ $25 \mathrm{~kg} / \mathrm{ha}$. Interaction effects, at 60 DAS, was maximum due to Aspergillus sp.+ZnO @25 $\mathrm{kg} / \mathrm{ha}(2.46 \mathrm{~cm})$ and Penicillium sp. + ZnO @ $25 \mathrm{~kg} / \mathrm{ha}(2.42 \mathrm{~cm})$ over RDF $(2.13 \mathrm{~cm})$ by $15.4 \%$ and $13.6 \%$.

The effect of varying nutrient levels on dry matter yield was significant (Table 3). Maximum and significant increase of yield was obtained by the application of $\mathrm{ZnO} @ 25$ $\mathrm{kg} / \mathrm{ha} \quad(63.73 \mathrm{~g} / \mathrm{plant})$ over RDF (61.21 $\mathrm{g} /$ plant) by $4.1 \%$ followed by application of $\mathrm{ZnO} @ 12.5 \mathrm{~kg} / \mathrm{ha}$ (63.01 g/plant) over the same by $2.9 \%$. All inoculants had a significant effect on dry matter yield with maximum input by Aspergillus sp. (63.21 g/plant) by $3.2 \%$ followed by Penicillium sp (63.19 $\mathrm{g} /$ plant) by $3.1 \%$ over no inoculation (61.83 $\mathrm{g} /$ plant), respectively. The interaction effect on dry matter yield ranged from $60.50 \mathrm{~g} /$ plant to $64.67 \mathrm{~g} /$ plant. Significantly maximum yield was obtained on inoculation of Aspergillus sp. $+\mathrm{ZnO} @ 25 \mathrm{~kg} / \mathrm{ha}$ followed by significant effects of Penicillium sp.+ ZnO@ 25 kg/ha with increase of $6.2 \%$ over RDF.

An increase in overall growth can be attributed to the synthesis and secretion of growth promoting substances by inoculants that carry out stem expansion, increased chlorophyll content and photosynthesis rate (Burd et al., 2000; Panhwar et al., 2011).
Rudresh et al., (2005) recorded the highest plant height of $34.6 \mathrm{~cm}$ in treatment, which received combined inoculation of Rhizobium, PSB and T. harzianum with rock phosphate over control in chickpea, Rafi et al., (2012) reported dual inoculation with Azospirillum strain A2 and PSB isolates resulted in maximum shoot height of foxtail millet (cv. Chitra) over contol. Wu et al., (2005) observed co-inoculation with $P$. chlororaphis and $A$. pascens amendment with RP resulted in the highest plant height in walnut seedling, a significant increment in plant height (45\%) and shoot length (19\%) over control was observed by Viruel et al., (2014) in maize treated with Pseudomonas tolaasii IEXb with $50 \mathrm{~kg}$ P per ha applied as TSP under pot and field trial. Srinivasan et al., (2012) reported that Aspergillus sp. PSFNRH-2 recorded the highest stem girth $(2.63 \mathrm{~cm})$, which was significantly higher than that recorded by all other fungal isolates $(0.80-2.20 \mathrm{~cm})$ including the reference strain, A. awamori $(2.30 \mathrm{~cm})$ but was on par with the SSP control $(2.70 \mathrm{~cm})$ in sorghum. Mfilinge et al., (2014) reported that Rhizobium inoculation with $30 \mathrm{~kg} / \mathrm{ha} \mathrm{P}$ application increased plant girth by $1.3 \% 6$ WAP in field experiment and $5.1 \%$ and $11.67 \%$ in green house for 3 WAP and 6 WAP respectively in bush bean. Akhtar et al., (2014) reported that integrated effect of Rhizobium and Bacillus spp. on the growth of maize (Zea Mays L.) with recommended dose of fertilizer (120-60 kg NP/ha) increased stem diameter $(15.43 \mathrm{~mm})$ over control. Mehrvarz et al., (2008) found significant increase in chlorophyll content of leaves of barley due to positive effect of phosphorous with microbes. Also he found that fungal inoculation was more effective in increasing chlorophyll content over bacterial inoculants due to antagonistic effects on it by chemical fertilizer. Panhwar et al., (2011) recorded highest chlorophyll content (29.30) was obtained in treatments with $\mathrm{P}$ at $60 \mathrm{~kg}$ per ha inoculated with PSB16 (Bacillus sp.) 
compared to non-inoculated treatments. Gupta and Gangwar (2012) in chickpea reported highest chlorophyll content $(6.20 \mathrm{mg} / \mathrm{g}$ fresh leaves) was observed with $1.0 \mathrm{~kg} \mathrm{AM} / \mathrm{ha}$ as soil application + Rhizobium + PSB +RDF. Abbas et al., (2013) also recorded higher chlorophyll content in maize with coinoculation between PGPR and reduced doses of nitrogen and phosphorous over chemical control. Sharma and Banik (2014) reported in maize plants grown with $100 \%$ recommended dose of fertilizer $(\mathrm{RDF})[\mathrm{N}$ : $\left.\left.\mathrm{P}_{2} \mathrm{O}_{5}: \mathrm{K}_{2} \mathrm{O}\right)=150: 60: 60 \mathrm{~kg} / \mathrm{hal}\right]+\mathrm{AM}+$ Azospirillum (T15) produced maximum chlorophyll over uninoculated control. Saxena et al., (2015) also recorded high chlorophyll content in maize on co inoculation with TCP over control. The increase in dry matter yield could be due to PGPR effect of inoculated microbe leading to high uptake of nutrients, increased photosynthesis, and increased growth of root and shoot organs, siderophore and phytohormone production, as well as to their capacity to colonize the root system and interact positively with the plant (Viruel et al., 2011). It could be attributed to the increased vegetative growth possibly as a result of effective utilization of nutrients absorbed through extensive root system and prolific shoot development on account of improved nourishment Kumawat et al., (2009). Vikram et al., (2008) in chickpea reported highest root dry matter by PSBV-5, PSBV-9 and PSBV-13 (all of which recorded $0.59 \mathrm{~g}$ ) while highest shoot and total dry matter was recorded by PSBV-14 (6.41 and $6.97 \mathrm{~g}$, respectively) with recommended dose of $\mathrm{P}$ in the form of MRP in comparison with SSP control and RP control. Kumawat et al., (2009) in mung bean reported that application of vermicompost, seed inoculation with PSB and $40 \mathrm{~kg}$ P2O5/ha significantly increased dry matter yield over control. Panhwar (2011) reported a significantly higher dry matter (21.48 g) in treatments with $60 \mathrm{~kg}$ P2O5 per ha inoculated with PSB16, while the response in the control treatment was very low in aerobic rice. Messele and Pant (2012) recorded that inoculation of Sinorhizobium ciceri + Pseudomonas sp. with $18 / 20 \mathrm{~kg}$ NP ha-1 as urea and DAP increased dry matter $181.40 \%$ respectively over uninoculated control at mid flowering stage in chickpea. Umesha et al., (2013) in a field experiment of maize reported that treatment (T13) having recommended dose of NPK + Azotobacter chroococcum + Bacillus megaterium + Pseudomonas fluorescence + enriched compost gave the highest total dry matter production at harvest (375.80 g) over uninoculated control.

\section{Nutrient content (\%)}

\section{$\mathrm{N}$ content}

Among various varying levels of nutrients higher dose of $\mathrm{ZnO}$ i.e., @ $25 \mathrm{~kg} / \mathrm{ha}$ showed maximum $\mathrm{N}$ content increases by $15.2 \%$ in maize (Table 4). The significant increase was also observed with lower level of $\mathrm{ZnO}$ application@ @ $12.5 \mathrm{~kg} / \mathrm{ha}(2.02 \%)$ over RDF by $9.7 \%$. Inoculation of different microorganisms also showed a significant increase in $\mathrm{N}$ content of maize. Among the inoculants, fungus Aspergillus showed maximum increase in $\mathrm{N}$ content $(2.42 \%)$ which is about $69.23 \%$ more over uninoculated control. Penicillium also contributed to a higher $\mathrm{N}$ content (2.23\%) by $55.9 \%$ more over uninoculated control. Bacillus megaterium and $B$. subtilis also showed significant results. In general, the trend was found that higher dose of nutrient level with inoculants provided more $\mathrm{N}$ content in maize. Variation among interactions in $\mathrm{N}$ content of maize varied widely from $1.27 \%$ to $2.37 \%$. Maximum N content perceived by interaction of Aspergillus sp. with the trearment of $\mathrm{ZnO} @ 25 \mathrm{~kg} / \mathrm{ha}$. All inoculants with RDF showed an increase in $\mathrm{N}$ content of maize by $56 \%$ to $60.6 \%$ when compared to $\mathrm{RDF}$ with no inoculation. 
Table.1 Influence of Zn solubilizers and nutrient levels on Plant height $(\mathrm{cm})$ at 30 and 60 DAS

\begin{tabular}{|c|c|c|c|c|c|c|c|c|}
\hline Isolate & RDF & $\begin{array}{r}\mathrm{ZnO} \\
(12.5 \\
\mathrm{kg} / \mathrm{ha})\end{array}$ & $\begin{array}{c}\text { ZnO } \\
(25 \\
\text { kg/ha) }\end{array}$ & Average & RDF & $\begin{array}{r}\mathrm{ZnO} \\
(12.5 \\
\mathrm{kg} / \mathrm{ha})\end{array}$ & $\begin{array}{c}\mathrm{ZnO} \\
(25 \\
\mathrm{kg} / \mathrm{ha})\end{array}$ & Average \\
\hline & \multicolumn{4}{|c|}{30 DAS } & \multicolumn{4}{|c|}{ 60 DAS } \\
\hline No inoculation & 38.43 & 38.33 & 39.10 & 38.62 & 112.83 & 118.33 & 117.33 & 116.16 \\
\hline B. megaterium & 42.00 & 41.60 & 47.30 & 43.63 & 118.00 & 128.67 & 130.00 & 125.55 \\
\hline B. subtilis & 45.23 & 47.20 & 48.30 & 46.91 & 118.33 & 126.67 & 131.67 & 126.11 \\
\hline Aspergillus sp. & 50.53 & 54.63 & 55.57 & 53.57 & 121.33 & 139.33 & 143.33 & 134.66 \\
\hline Penicillium sp. & 47.70 & 52.80 & 52.40 & 50.96 & 120.00 & 123.67 & 139.33 & 127.66 \\
\hline \multirow[t]{2}{*}{ Average } & 44.78 & 46.91 & 48.53 & 46.74 & 118.10 & 127.33 & 132.33 & 125.92 \\
\hline & Nutrient & & Isolate & $\begin{array}{l}\text { Nutrient } \\
\text { X Isolate }\end{array}$ & Nutrient & Isolate & & $\begin{array}{l}\text { Nutrient } \\
\text { X Isolate }\end{array}$ \\
\hline S.Em \pm & 0.34 & & 0.34 & 0.58 & 0.41 & 0.41 & & 0.92 \\
\hline CD at $5 \%$ & 0.96 & & 0.96 & 2.15 & 1.17 & 1.17 & & 2.61 \\
\hline
\end{tabular}

Table.2 Impact of $\mathrm{Zn}$ and $\mathrm{P}$ solubilizing microbes and varying nutrient levels on stem girth $(\mathrm{cm})$ at 30 and 60 DAS

\begin{tabular}{|c|c|c|c|c|c|c|c|c|}
\hline Isolate & RDF & $\begin{array}{c}\mathrm{ZnO} \\
(12.5 \\
\mathrm{kg} / \mathrm{ha})\end{array}$ & $\begin{array}{c}\mathrm{ZnO} \\
(25 \\
\mathrm{kg} / \mathrm{ha})\end{array}$ & Average & RDF & $\begin{array}{c}\mathrm{ZnO} \\
(12.5 \\
\mathrm{kg} / \mathrm{ha})\end{array}$ & $\begin{array}{c}\mathrm{ZnO} \\
(25 \\
\mathrm{kg} / \mathrm{ha})\end{array}$ & Average \\
\hline & \multicolumn{4}{|c|}{30 DAS } & \multicolumn{4}{|c|}{60 DAS } \\
\hline $\begin{array}{c}\text { No } \\
\text { inoculation }\end{array}$ & 1.23 & 1.33 & 1.28 & 1.28 & 2.13 & 2.22 & 2.34 & 2.23 \\
\hline $\begin{array}{c}B . \\
\text { megaterium }\end{array}$ & 1.44 & 1.55 & 1.83 & 1.60 & 2.31 & 2.37 & 2.36 & 2.34 \\
\hline B. subtilis & 1.43 & 1.55 & 1.69 & 1.55 & 2.26 & 2.32 & 2.35 & 2.31 \\
\hline $\begin{array}{l}\text { Aspergillus } \\
\text { sp. }\end{array}$ & 1.58 & 1.83 & 1.89 & 1.76 & 2.38 & 2.42 & 2.47 & 2.43 \\
\hline $\begin{array}{l}\text { Penicillium } \\
\text { sp. }\end{array}$ & 1.47 & 1.63 & 1.77 & 1.62 & 2.37 & 2.45 & 2.46 & 2.42 \\
\hline Average & 1.43 & 1.58 & 1.69 & & 2.29 & 2.36 & 2.39 & \\
\hline & Nutrient & & Isolate & $\begin{array}{c}\text { Nutrient } \\
\mathbf{X} \\
\text { Isolate }\end{array}$ & Nutrient & Isolate & & $\begin{array}{c}\text { Nutrient } \\
X \\
\text { Isolate }\end{array}$ \\
\hline S.Em \pm & 0.01 & & 0.01 & 0.02 & 0.01 & 0.01 & & 0.02 \\
\hline CD at $5 \%$ & 0.03 & & 0.03 & 0.06 & 0.02 & 0.02 & & 0.05 \\
\hline
\end{tabular}


Table.3 Effect of nutrient sources and $\mathrm{P}$ and $\mathrm{Zn}$ solubilizers on dry matter yield (g/plant) of maize

\begin{tabular}{|c|c|c|c|c|}
\hline Nutrient & RDF & $\begin{array}{c}\text { ZnO (12.5 } \\
\mathbf{k g} / \mathbf{h a})\end{array}$ & $\begin{array}{c}\mathbf{Z n O} \mathbf{( 2 5} \\
\mathbf{k g} / \mathbf{h a})\end{array}$ & Average \\
\hline Isolate & & 61.167 & 62.113 & 61.256 \\
\hline No inoculation & 60.500 & 63.997 & 63.587 & 62.934 \\
\hline B. megaterium & 61.243 & 63.580 & 63.157 & 62.651 \\
\hline Aspergillus sp. & 61.247 & 63.590 & 64.670 & 63.216 \\
\hline Penicillium sp. & 61.373 & 64.297 & 63.587 & 63.191 \\
\hline Average & 61.707 & 63.017 & 63.731 & 62.650 \\
\hline & Nutrient & Isolate & & Nutrient X Isolate \\
\hline S.Em \pm & 0.069 & 0.069 & & 0.154 \\
\hline CD at 5\% & 0.196 & 0.196 & & 0.439 \\
\hline
\end{tabular}

Table.4 Influence of different inoculants and nutrient levels on $\mathrm{N}$ and P contents (\%) in maize after harvest

\begin{tabular}{|c|c|c|c|c|c|c|c|c|}
\hline Isolate & RDF & $\begin{array}{c}\mathrm{ZnO} \\
(12.5 \\
\mathrm{kg} / \mathrm{ha})\end{array}$ & $\begin{array}{c}\mathrm{ZnO} \\
(25 \\
\mathrm{kg} / \mathrm{ha})\end{array}$ & Average & RDF & $\begin{array}{c}\mathrm{ZnO} \\
(12.5 \\
\mathrm{kg} / \mathrm{ha})\end{array}$ & $\begin{array}{c}\mathrm{ZnO} \\
(25 \\
\mathrm{kg} / \mathrm{ha})\end{array}$ & Average \\
\hline & \multicolumn{4}{|c|}{$\mathbf{N}$} & \multicolumn{4}{|c|}{$\mathbf{P}$} \\
\hline $\begin{array}{c}\text { No } \\
\text { inoculation }\end{array}$ & 1.27 & 1.43 & 1.43 & 1.37 & 0.307 & 0.321 & 0.319 & 0.315 \\
\hline $\begin{array}{c}B . \\
\text { megaterium }\end{array}$ & 1.98 & 2.06 & 2.07 & 2.03 & 0.427 & 0.431 & 0.432 & 0.429 \\
\hline B. subtilis & 1.93 & 2.04 & 2.05 & 2.00 & 0.424 & 0.424 & 0.416 & 0.425 \\
\hline $\begin{array}{l}\text { Aspergillus } \\
\text { sp. }\end{array}$ & 2.04 & 2.35 & 2.69 & 2.36 & 0.426 & 0.435 & 0.437 & 0.432 \\
\hline $\begin{array}{l}\text { Penicillium } \\
\text { sp. }\end{array}$ & 1.99 & 2.19 & 2.37 & 2.18 & 0.435 & 0.432 & 0.435 & 0.431 \\
\hline \multirow[t]{2}{*}{ Average } & 1.84 & 2.02 & 2.12 & & 0.404 & 0.409 & 0.408 & \\
\hline & Nutrient & & Isolate & $\begin{array}{c}\text { Nutrient } \\
\mathbf{X} \\
\text { Isolate }\end{array}$ & Nutrient & Isolate & & $\begin{array}{l}\text { Nutrient } \\
\text { X Isolate }\end{array}$ \\
\hline S.Em \pm & 0.02 & & 0.02 & 0.05 & 0.002 & 0.002 & & 0.004 \\
\hline CD at $5 \%$ & 0.06 & & 0.06 & 0.13 & 0.007 & 0.007 & & 0.012 \\
\hline
\end{tabular}


Table.5 Influence of different inoculants and nutrient levels on $\mathrm{K}$ and $\mathrm{Zn}$ contents (\% and ppm) in maize after harvest

\begin{tabular}{|c|c|c|c|c|c|c|c|c|}
\hline Isolate & RDF & $\begin{array}{c}\text { ZnO } \\
(12.5 \\
\text { kg/ha) }\end{array}$ & $\begin{array}{c}\text { ZnO } \\
(25 \\
\text { kg/ha) }\end{array}$ & Average & RDF & $\begin{array}{c}\mathrm{ZnO} \\
(12.5 \\
\mathrm{kg} / \mathrm{ha})\end{array}$ & $\begin{array}{c}\mathrm{ZnO} \\
(25 \\
\mathrm{kg} / \mathrm{ha})\end{array}$ & Average \\
\hline & & K & & & \multicolumn{4}{|c|}{$\mathrm{Zn}$} \\
\hline $\begin{array}{c}\text { No } \\
\text { inoculation }\end{array}$ & 1.25 & 1.23 & 1.24 & 1.24 & 14.88 & 24.95 & 24.46 & 21.43 \\
\hline $\begin{array}{c}B . \\
\text { megaterium }\end{array}$ & 1.35 & 1.54 & 1.55 & 1.48 & 19.62 & 26.10 & 26.02 & 23.91 \\
\hline B. subtilis & 1.35 & 1.51 & 1.53 & 1.46 & 20.38 & 24.61 & 26.04 & 23.72 \\
\hline $\begin{array}{l}\text { Aspergillus } \\
\text { sp. }\end{array}$ & 1.45 & 1.55 & 1.62 & 1.54 & 23.43 & 27.24 & 26.72 & 25.79 \\
\hline $\begin{array}{l}\text { Penicillium } \\
\text { sp. }\end{array}$ & 1.43 & 1.54 & 1.57 & 1.50 & 22.10 & 24.76 & 26.19 & 24.30 \\
\hline Average & 1.36 & 1.48 & 1.50 & & 20.08 & 25.53 & 25.89 & \\
\hline & Nutrient & & Isolate & $\begin{array}{c}\text { Nutrient } \\
\mathbf{X} \\
\text { Isolate }\end{array}$ & Nutrient & Isolate & & $\begin{array}{c}\text { Nutrient } \\
\mathbf{X} \\
\text { Isolate }\end{array}$ \\
\hline S.Em \pm & 0.01 & & 0.01 & 0.04 & 0.34 & 0.34 & & 0.76 \\
\hline CD at $5 \%$ & 0.02 & & 0.02 & 0.07 & 0.97 & 0.97 & & 2.16 \\
\hline
\end{tabular}

Fig.1 Available zinc (ppm) released by bacteria in broth medium containing zinc oxide

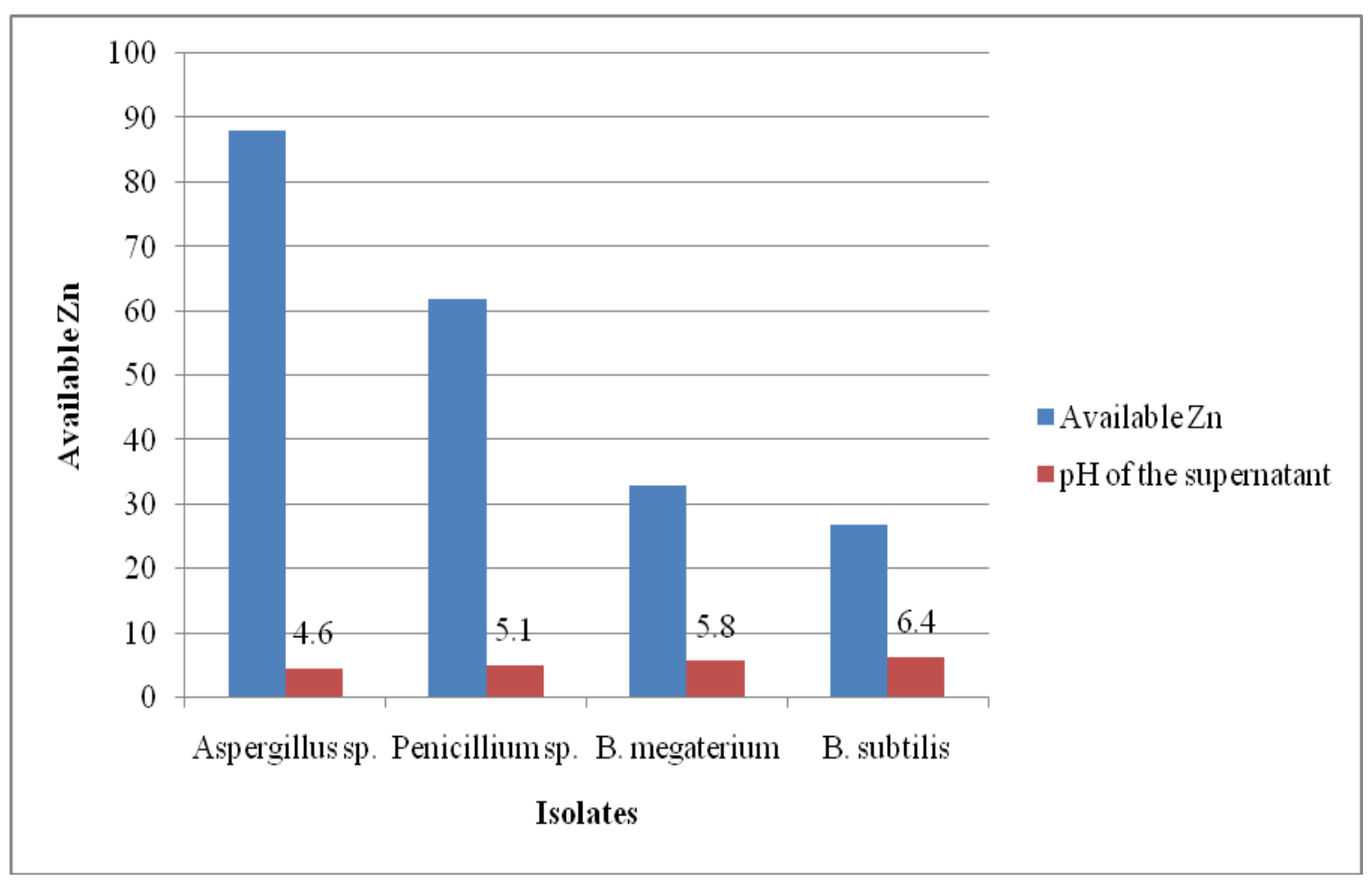




\section{$P$ content}

Among the different levels of nutrient applied $\mathrm{ZnO} @ 25 \mathrm{~kg} / \mathrm{ha}$ shows maximum P content $(0.409 \%)$ in maize. This was followed by $\mathrm{ZnO} @ 12.5 \mathrm{~kg} / \mathrm{ha}$ application $(0.408 \%)$. Inoculation of different strains of $\mathrm{Zn}$ solubilizers had a profound increase in $\mathrm{P} \%$ content over uninoculated treatments by 36.2 to 37.1 per cent (Table 4). Maximum average $\mathrm{P}$ content was found by inoculation with Aspergillus $(0.432 \%)$. The bacterial inoculants $B$. megaterium and $B$. subtilis performed better than no inoculation in $\mathrm{P}$ content by 34 to 36 per cent. Interaction among nutrient levels and inoculants showed a positive response on $\mathrm{P}$ content in maize. Maximum $\mathrm{P}$ content was found between Aspergillus + ZnO @ $25 \mathrm{~kg} / \mathrm{ha}(0.437 \%)$ whereas, Penicillkium + ZnO @ 25 kg/ha and B. megaterium $+\mathrm{ZnO}$ @ $25 \mathrm{~kg} /$ ha performed suitably well.

\section{K content}

Influence of different nutrient levels had significant effect on $\mathrm{K}$ content in maize being maximum with $10.2 \%$ increase with application of $\mathrm{ZnO} @ 25 \mathrm{~kg} / \mathrm{ha}$ over RDF (Table 5). It was closely followed by application of $\mathrm{ZnO} @ 12.5 \mathrm{~kg} / \mathrm{ha}$ with significant increase of $8.8 \%$ over RDF. Influence of incorporation of inoculants also provided a good $\mathrm{K}$ content in maize. Maximum $\mathrm{K}$ content was observed by inoculation of Aspergillus sp. with an increase of $24.1 \%$ over uninoculated control. Inoculation of Penicillium and B. megaterium contributed 1.50 and 1.48 per cent $\mathrm{K}$ content which was $20.9 \%$ and $19.3 \%$ more over no inoculation. Interaction effect of nutrient levels and inoculants was found to be significant over their respective controls. Profound effect was observed by interaction of Aspergillus sp.+ ZnO @ 25 kg/ha with an increase of $29.6 \%$ over RDF followed by
Penicillium sp. + ZnO @ 25kg/ha and $B$. megaterium sp.+ZnO@25 kg/ha with an increase of 25.6 and 24 per cent, respectively over RDF.

\section{Zn content (ppm)}

Effect of varying nutrient levels showed significant results of $\mathrm{Zn}$ content over RDF being maximum increase of $29.0 \%$ with an application of $\mathrm{ZnO} @ 25 \mathrm{~kg} / \mathrm{ha}$ followed by application of $\mathrm{ZnO} @ 12.5 \mathrm{~kg} / \mathrm{ha}$ with $27.1 \%$ increase over RDF (Table 5). Incorporation of microbial inoculants significantly improved the $\mathrm{Zn}$ content in the maize plant compared with uninoculated control. Inoculation of Aspergillus sp. showed significantly greatest impact on $\mathrm{Zn}$ content by $20.3 \%$ over no inoculation followed by Penicillium sp. with increase of 13.3 per cent over RDF. Comparable results were obtained on inoculation with both bacterial inoculants. In general, significantly more $\mathrm{Zn}$ content was observed with inoculants at both level of $\mathrm{ZnO}$. Significant interaction effects between Aspergillus sp. + ZnO @ $25 \mathrm{~kg} / \mathrm{ha}$ showed maximum $\mathrm{Zn}$ content in maize by $83 \%$ over RDF followed by inoculation of Penicillium sp. with the same with $76 \%$ increase over RDF.

The present study indicated that microbial inoculation of maize with $Z n$ solubilizers significantly enhanced the $\mathrm{N}, \mathrm{K}$ and $\mathrm{P}$ content in maize plants. This enhanced uptake of these major nutrients when compared to uninoculated plants could be explained on the basis that the unavailable forms of these nutrients were solubilized and made available near the root region of soil by applying these plant growth promoting isolates. Plants inoculated with these nutrient solubilizing microbes usually had more nitrogen content than that of uninoculated plants (Punte et al., 2004). This is further reinforced by experiments conducted by Murty and Ladha 
(1988) who revealed that Azospirillum inoculation increased ammonium and phosphate uptake in rice. Even $\mathrm{K}^{+}$ concentration was more in treatments other than control. Results showed that all fungal treated plants showed significant improvement in their $\mathrm{Zn}$ content over bacterial and control ones in maize. The enhancement of macro and $\mathrm{Zn}$ uptake by plants by inoculation with these isolates may be due to their effect on growth and development of lateral roots (Rolfe et al., 1997), increased root volume and weight, and nutrient uptake (Canbolat et al., 2006). Studies done by Goldstein and Liu, 1997 demonstrated that phosphate and potash solubilizing bacteria may enhance mineral uptake in plants. This was confirmed in the study due to higher percentage of macro nutrients content evaluated in maize was significantly and/or relatively increased in inoculated plants. On observing the both $\mathrm{Zn}$ levels of treatments it can be remarked that higher dosage $\mathrm{ZnO}$ recorded more $\mathrm{Zn}$ content in plants but it was less compared to the interaction effect of it with various isolates. This may be due to the fact that presence of readily available $\mathrm{Zn}$ source in soil itself is not sufficient for uptake, but also the mobility of mineral element itself is required. This difficulty was overcome on inoculation of an isolate which helped in its migration to plant roots and hence, in its increased uptake. On the basis of the performance of these four isolates with different dosage of nutrient sources it was confirmed that Aspergillus sp. was the best in terms of $\mathrm{Zn}$ solubilization and its uptake in plants. Also the fungal species performed comparatively better than the bacteria ones which can be correlated to more acid production. Kumawat et al., (2009) reported that application of vermicompost at 2t/ha, seed inoculation with PSB and $40 \mathrm{~kg}$ $\mathrm{P} 2 \mathrm{O}$ /ha significantly increased the $\mathrm{N}, \mathrm{P}$ and $\mathrm{K}$ concentration in seed, straw and their total uptake in mung bean. Kumar et al., (2013) reported increased $\mathrm{N}, \mathrm{P}, \mathrm{K}$ content and uptake in mung bean due to PSB inoculation with SSP over uninoculated control. The enhancement in nutrient content and uptake by inoculation with insoluble sources may be due to the production of low molecular weight, organic acid and subsequent release of $\mathrm{Zn}$ from insoluble compounds by reducing sorption of $\mathrm{Zn}$ by altering the surface charge of soil colloids Jones (1998). It may also be due to the fact that initiation of development of lateral roots and increased root weight Rolfe et al., (1997), Canbolat et al., (2006). Increased $\mathrm{Zn}$ content and uptake by plants due to incorporation of inoculants at various $\mathrm{P}$ sources were also reported by Whiting et al., (2001), Tariq et al., (2007) in wheat, Joshi et al., (2013) in wheat, Goteti et al., (2013) in maize and Ramesh et al., (2014) in soybean and wheat.

In our study with $\mathrm{Zn}$ solubilizing isolates and its effect on inoculation upom maize for plant growth promoting activities it revealed that inoculation with such beneficial microorganisms is an efficient method for enhancing growth of maize and help in its nourishment over no inoculation. Aspergillus sp. could be effectively used as bio input for improving the plant growth and yield. Moreover all these four isolates can be used as a substitute and/or with integration to chemical fertilizers to correct the nutrient deficiencies in crops depending on situation for increased productivity and better plant nutrition in a sustainable manner.

\section{References}

Abbas, Z., Zia, M. A., Ali, S., Abbas, Z. and Waheed, A. 2013. Integrated effect of plant growth promoting rhizobacteria, phosphate solubilizing bacteria and chemical fertilizers on growth of maize. International Journal of Agriculture and Crop Sciences, 6(13): 913- 921. 
Akhtar, K., Shah, N. M. and Ali, A. 2014. Effects of humic acid and crop residues on soil and wheat nitrogen contents. American Journal of Plant Sciences, 5: 1277-1284.

Burd, G.I.; Dixon, G.D. and Glick, B.R. 2000. A plant growth promoting bacterium that decreases heavy metal toxicity in plants. Canadian Journal of Microbiology, 46: 237-245.

Cakmak, I. 2008. Enrichment of cereal grains with zinc: Agronomic or genetic biofortification? Plant and Soil. 302:117.

Canbolat, M. Y., Bilen, S., Çakmakç, R. and Aydın, F. S. A. 2006. Effect of plant growth-promoting bacteria and soil compaction on barley seedling growth, nutrient uptake, soil properties and rhizosphere microflora. Biology and Fertility of Soils, 42: 350- 357.

Coutinho, F. P.; Felix, W. P. and Yano-Melo A. M. (2012). Solubilization of phosphates in vitro by Aspergillus spp. and Penicillium spp. Ecological Engineering, 42: 85-89.

Crane, F. L., Sun, I. L., Sun, E. and Morré, D. J. 1991. Alternative functions for coenzyme $\mathrm{Q}$ in endomembranes, in $\mathrm{K}$. Folkers, G.P. Littarru and T. Yamagami (eds.), Biomedical and Clinical Aspects of Coenzyme $Q$, Elsevier Science Publishers, Amsterdam, pp. 59-70.

Desai, S., Kumar, P., Sultana, S., Pinisetty, S., Ahmed, S. K. M. H., Amalraj, E. L. D. and Reddy, G. 2012. Potential microbial candidate strains for management of nutrient requirements of crops. Afr. $J$. Microbiol. Res., 6:3924-3931.

Di Simine, C.D., Sayer, J.A. and Gadd, G.M. 1998. Solubilization of zinc phosphate by a strain of Pseudomonas fluorescens isolated from a forest soil. Biology and Fertility of Soils 28: 87-94.

Fasim, F., Ahmed, N., Parsons, R. and Gadd,
G.M. 2002. Solubilization of zinc salts by the bacterium isolated by the air environment of tannery. FEMS Microbiology Letters, 213: 1-6.

Goldstein, A. H., Krishnaraj, P.U. 2007 Phosphate solubilizing microorganisms vs. phosphate mobilizing microorganisms: what separates a phenotype from a trait? In: Velázquez E, Rodríguez-Barrueco C (eds) First International meeting on microbial phosphate solubilization. Springer, Dordrecht, pp 203-213.

Gomez, K. A. and Gomez, A. A. 1984. Statistical procedures for agricultural research, 2nd edition. John Wiley and Sons, New York, pp. 680.

Goteti, P. K., Emmanuel, L. D. A., Desai, S., \& Shaik, M. H. A. 2013. Prospective Zinc Solubilising Bacteria for Enhanced Nutrient Uptake and Growth Promotion in Maize (Zea mays L.). International Journal of Microbiology, 2013: 1-7.

Gupta, S. C. and Gangwar, S. 2012. Effect of molybdenum, iron and microbial inoculants on symbiotic traits, nutrient uptake and yield of chickpea. Journal of Food Legumes. 25(1): 45-49.

Hughes M. N. and Poole, R. K. 1991. Review article. Metal speciation and microbial growth - the hard (and soft) facts. J Gen Microbiol. 137:725-734.

Jones D. L. 1998. Organic acids in the rhizosphere: A critical review. Plant and Soil, 205: 25-44.

Joshi, D., Negi, G., Vaid, S. and Sharma, A. 2013. Enhancement of Wheat Growth and $\mathrm{Zn}$ Content in Grains by Zinc Solubilizing Bacteria. International Journal of Agriculture, Environment \& Biotechnology. 6(3): 363-370.

Kumar, A.; Maurya, B. and Raghuwansh, R. 2013. Isolation and characterization of PGPR and their effect on growth, yield and nutrient content in wheat (Triticum aestivum L.). Biocatalysis and 
Agricultural Biotechnology. 3: 121128.

Kumawat, N., Singh, R. and Kumar, A. 2013. Effect of integrated nutrient management on the performance of sole and intercropped pigeonpea (Cajanus cajan) under rainfed conditions. Indian Journal of Agronomy, 58(3): 309-315.

Mehrvarz, S., Chaichi, M. R. and Alikhani, H. A. 2008. Effect of phosphate solubilizing microorganisms and phosphorus chemical fertilizer on forage and grain quality of barley (Hordeum vulgare L.). American- Eurasian Journal of Agricultural and Environmental. 23(4): 215-221.

Messele, B. and Pant, L. M. 2012. Effects of inoculation of Sinorhizobium ciceri and phosphate solubilizing bacteria on nodulation, yield and nitrogen and phosphorus uptake of chickpea (Cicer arietinum L.) in Shoa Robit area. Journal of Biofertility and Biopesticide, 3: 129-133.

Mfilinge, A., Kevin, M., Patrick, A. and Ndakidemi, K. 2014. Effects of Rhizobium inoculation and supplementation with $\mathrm{P}$ and $\mathrm{K}$, on growth, leaf chlorophyll content and nitrogen fixation of bush bean varieties. American Journal of Research Communication, 2(10): 49-87.

Olsen, S. R., Cole, C. V., Watanabe, F. S., and Dean, L. A. 1954. Estimation of available phosphorus in soils by extraction with sodium bicarbonate. Circular, vol. 939 (p. 19). Washington, DC: US Department of Agriculture.

Panhwar, Q. A.; Radziah, O. and Zaharah, A. 2011. Role of phosphate solubilizing bacteria on rock phosphate solubility and growth of aerobic rice. Journal of Environmental Biology, 32: 607-612.

Puente, M. E., Rodriguez-Jaramillo, M. C., Li, C. Y., and Bashan, Y. 2006. Image analysis for quantification of bacterial rock weathering. J. Microbiol. Methods, 64: 275-286.

Rafi, M. M. D., Varalakshmi, T. and Charyulu, P. B. B. N. 2012. Influence of Azospirillum and PSB inoculation on growth and yield of Foxtail Millet. Journal of Microbiological and Biotechnological Research, 2(4): 558565.

Ramesh, A., Sushil, K., Sharma, M. P., Yadav, N. and Joshi, O. P. 2014. Inoculation of zinc solubilising Bacillus aryabhattai strains for improved growth, mobilization and biofortification of zinc in soybean and wheat cultivated in Vertisols of central India. Applied Soil Ecology, 73: 87- 96.

Rolfe, B. G., Djordjevic, M. A., Weinman, J. J., Mathesius, U., Pittock, C., Gartner, E., Ride, K. M., Dong, Z. M., Mccully, M. and McIver, J. 1997. Root morphogenesis in legumes and cereals and the effect of bacterial inoculation on root development. Plant and Soil, 194: 131-144Rudresh, D.; Shivaprakasha, M. and Prasad, R. 2005. Effect of combined application of Rhizobium, phosphate solubilizing bacterium and Trichoderma spp. on growth, nutrient uptake and yield of chickpea (Cicer aritenium L.). Applied Soil Ecology. 28: 139-146.

Saravanan, V. S., Subramonium, S. R. and Raj, S. A. 2003. Assessing in vitro solubilization potential of different zinc solubilizing bacterial (ZSB) isolates. Brazilian Journal of Microbiology, 34:121-125.

Saxena, J., Saini, A., Ravi, I., Chandra, S. and Garg, V. 2015. Consortium of phosphate-solubilizing bacteria and fungi for promotion of growth and yield of chickpea (Cicer arietinum). Journal of Crop Improvement, 29(3):42-47.

Sharma, P. N., Chatterjee, C., Agarwala, S. C., and Sharma, C. P. 1990. Zinc 
deficiency and pollen fertility in maize (Zea mays). Plant Soil, 124:221-225.

Sharma, S. K., Sharma, M. P., Ramesh, A. and Joshi, O. P. J. 2012. Characterization of Zinc-Solubilizing Bacillus Isolates and their Potential to Influence Zinc Assimilation in Soybean Seeds. Microbiology and Biotechnology, 22(3): 352- 359.

Srinivasan, R., Yandigeri, M., Kashyap, S. and Alagawadi, A. 2012. Effect of salt on survival and P-solubilization potential of phosphate solubilizing microorganisms from salt affected soils. Saudi Journal of Biological Sciences. 19: 427-434.

Tandon, H. L. S., 1995. Methods of Analysis of Soils, Plants, Waters and Fertilizers. Fertilizer Development and Consultation Organization, Pamposh Enclave, New Delhi.

Tariq, M., Hameed, S., Malik, K. A. and Hafeez, F. Y. 2007. Plant root associated bacteria for zinc mobilization in rice. Pakistan Journal of Botany, 39: 245- 253.

Umesha, S., Divya, M., Prasanna, K. S., Lakshmipathi, R. N. and Sreeramulu, K. R. 2014. Comparative effect of organics and biofertilizers on growth and yield of maize (Zea mays. L). Current Agriculture Research, 2(1):118-123.

Vikram, A. and Hamzehzarghani, H. 2008. Effect of phosphate solubilizing bacteria on nodulation and growth parameters of greengram (Vigna radiata $\mathrm{L}$. Wilczek). Research Journal of Microbiology, 3: 62-72.

Viruel, E., Erazzu, L. E., Calsina, L. M., Ferrero, M. A., Lucca, M. E. and Sineriz, F. 2014. Inoculation of maize with phosphate solubilizing bacteria: effect on plant growth and yield. Journal of Soil Science and Plant Nutriton, 14(4):819-831.

Wakatsuki, T. 1995. Metal oxidoreduction by microbial cells. Journal of Industrial Microbiology, 14(2):169-177.

Whiting, S. N., de Souza, M. P. and Terry, N. 2001. Rhizosphere bacteria mobilize $\mathrm{Zn}$ for hyperaccumulation by Thlaspi caerulescens. Environmental Sciences and Technology, 35(15): 3144-3150.

Wu, S. C., Cao, Z. H., Li, Z. G., Cheung, K. C. and Wong, M. H. 2005. Effects of biofertilizer containing $\mathrm{N}$-fixer, $\mathrm{P}$ and $\mathrm{K}$ solubilizers and AM fungi on maize growth: A greenhouse trial. Geoderma, 125: $155-166$.

\section{How to cite this article:}

Sukanya Ghosh, Navneet Pareek, K. P. Rawerkar, R. Chandra, S. P. Pachauri and Shikhar Kaushik. 2019. Prospective Zinc Solubilizing Microorganisms for Enhanced Growth and Nutrition in Maize (Zea mays L.). Int.J.Curr.Microbiol.App.Sci. 8(08): 2771-2784. doi: https://doi.org/10.20546/ijcmas.2019.808.319 